\title{
The Financialization of Entity Enterprises and Audit Fees
}

\author{
Sun $\mathrm{Lu}^{1}$, Liang Yuewen ${ }^{1}$, Wen Xian ${ }^{1}$ \\ ${ }^{1}$ Sichuan University, Business School, Sichuan, P.R. China
}

\begin{abstract}
This paper studies the impact of entity enterprises financialization on audit fees and its internal mechanisms. We use the data of China's Shenzhen A-share listed companies from 2013 to 2018 to conduct empirical research. It is found that the higher the degree of financialization of the entity enterpeises, the higher the audit cost of the enterprise. The internal mechanism is that the level of the non-financial financialization is rising, leading to the reduction of information transparency of enterprises, which increases the audit risk faced by certified public accountants, so as to raise audit fees for risk compensation and self-protection. This paper provides a new perspective for understanding the financialization of entity enterprises, enriching the research results on financialization and audit fees of entity enterprises. The relevant conclusions have certain reference value for listed companies and regulatory authorities.
\end{abstract}

\section{Introduction}

The trend of financialization of entity enterprises is a major feature of China's current economy. The contribution of the financial industry to the GDP is gradually increasing, and the profit obtained by the financial industry is also substantially higher than that of other industries. In contrast, the real economy is slowing down due to overcapacity, low-end industrial chain and other problems, and the excessive expansion of the virtual economy leads to the structural imbalance between the real economy and the virtual economy. Therefore, since 2016, the state has continuously implemented new policies to carry out supply-side reform and revitalize the development of the real economy. At the same time, the academic circle also conducts a lot of research on financialization of entity enterprises. But there is a lack of further research on whether financialization of entity enterprises will affect audit fees and their internal mechanism.

As an important economic relationship between clients and certified public accountants, audit fees are an important object of audit research. Most of the influencing factors of audit fees are around the cost of audit products, the expected loss cost and the intensity of competition in the audit market [16], [2]. Li Xinzi et al. [23] analyzed from the perspective of auditor identification risk, and found that the more financial assets allocated by entity enterprises, the more likely it is to increase the operational risk or financial reporting risk of entity enterprises, and the higher the audit fee charged by auditors. Corporate transparency refers to the degree of public disclosure of corporate financial and management information. Investors often make judgments and decisions based on the information disclosed by enterprises [10]. The lower the information transparency is, the more unfavorable it is for investors to have a comprehensive and objective understanding of the company's real performance, which significantly increases the audit risk assessed by certified public accountants [8],[1]. Will the financialization of entity enterprises affect the information transparency of enterprises and thus the audit fees of enterprises? No study has provided direct evidence.

Based on this, this paper attempts to explore (1) the impact of financialization of entity enterprises on audit fees. (2) what is the effect mechanism of financialization of entity enterprises on audit fees? Based on the data of a-share listed companies in Shenzhen from 2013 to 2018, we found that financialization of entity enterprises would significantly increase audit fees. The internal mechanism is that the financialization of the non-financial enterprise reduces the information transparency of the company, thus increasing the audit risk of certified public accountants, and thus increasing the audit fees.

This paper may have the following three contributions: firstly, from the perspective of financialization of entity enterprises, this paper studies the issue of audit fees and supplements the existing literature. Secondly, this paper investigates the internal mechanism of financialization of entity enterprises to charge for auditing, which has certain practical significance for preventing financialization of entity enterprises in the future. Thirdly, this paper is helpful for capital market participants to make a more comprehensive and accurate evaluation of the economic consequences of financialization of entity enterprises.

The follow-up arrangement of this paper is as follows: the second part reviews the relevant literature and puts forward the research hypothesis of this paper; The third 
part is the data and research design; The fourth part is the conclusion and suggestions.

\section{Theoretical analysis and Hypothesis}

\subsection{Financialization and audit fees of entity enterprises}

The financialization of entity enterprises can not be accomplished overnight. The existing literature has made a lot of analysis from the macro level and micro level. For example, the "investment alternative" theory of financial assets [7], the "speculative arbitrage" motive [21], the precautionary saving motive [18],[21].

Audit risk and audit input are important factors in determining audit fees. On the one hand, the current riskoriented audit mode, in carrying out audit work, auditors to fully understand and evaluate customer risk of material misstatement in financial report, and according to the result of risk assessment to determine the nature of the audit procedures, time and scope, the auditors if not found or failing to report the customer financial reporting the major fault, will increase the audit risk to the auditor [12].

Financial investment and physical investment are actually a substitution relationship [19]. Given a certain amount of resources, if the entity enterprise devotes more resources to short-term financial investment, the non-financial investment for the long term will decrease, resulting in the hollowing out of the entity enterprise [13],[20], meanwhile, also reduce the willingness and motivation of enterprise innovation and crowd out enterprise innovation [15], resulting in the misallocation of internal resources, which has a negative impact on the performance of the main industry and the value of the entity enterprise in the future [21]. The increase of operational risk causes auditors to regard financialization as a matter of high audit risk. The audit risk that the auditor faces increases, will raise the audit charge to undertake the risk compensation and the self-protection.

On the other hand, the more the audit input, the higher the audit fee will be. Modern risk-oriented audit mode requires certified public accountants to link misstatement risk with operational risk and give systematic and overall audit opinions. Therefore, the fair value of financial assets need to be certified public accountants in risk assessment and control test link to obtain the auditees in operating conditions, a degree of good faith and with the external environment, financial market information, increased the complexity of audit, and lead to collect audit evidence of certified public accountants of time and energy to increase [4], [5]. The increase of audit input causes audit fee increased. The higher the degree of financialization of physical enterprises, the more complex the economic activities of enterprises, the more difficult it is for auditors to rely on the traditional experience and common sense of the real economy to provide audit services, the higher the requirements for auditors, and the increased input of auditors, leading to higher audit fees [3].
Combined with the causes of financialization of enterprises and related studies, this paper speculated that the "crowding out" effect of financialization of entity enterprises would reduce the non-financial investment conducive to the long-term development of enterprises, affect the innovation input of enterprises, reduce the competitiveness and performance of enterprises, and lead to the increase of audit risks faced by certified public accountants. The higher the degree of financialization of enterprises, the greater the complexity of economic activities, leading to more investment in the audit of certified public accountants, from the increase of audit fees. Therefore, the hypothesis is put forward:the higher the level of financialization of entity enterprises, the higher the audit fees(H1).

\subsection{Mediating effect of information transparency}

Enterprise information transparency refers to the openness of specific information of enterprises. One is financial transparency, which refers to the intensity and timeliness of financial information disclosure and is transmitted by analysts and media. The other is governance transparency, which refers to the strength of corporate governance information disclosure, which needs to be explained by the management authority for investors [6]. Enterprises often use short-term performance indicators to measure the value and contribution of managers. Managers tend to weaken the long-term development goal of the enterprise and choose projects with short cycle, high return and fast growth in order to maximize their own interests from the expansion of the company's scale and capital [17] in order to stabilize occupational safety and increase salary. However, financial assets themselves have the characteristics of high volatility of returns and poor persistence, Jin and Myers [11] point out that when a company encounters some bad news, such as poor business performance or an investment failure, the management may withhold these bad news for the sake of protecting its position and compensation, resulting in the opacity of the company's information. Lu Chuang et al. [24] found in their study that if the capital that should have been used for industrial investment is used to allocate financial assets to obtain short-term profits, the short-sighted behavior and speculative psychology of the management will be enhanced, and they are more inclined to hide the bad news. Peng Yuchao et al. [25]found that when corporate management increased financial investment for the purpose of speculation, financial investment was a convenient tool for the management to adjust profits, which could play a role of whitewashing short-term performance and market performance, and bad news about corporate prospects could also be temporarily hidden. We believe that financialization of entity enterprises will affect the disclosure of corporate governance information and lead to the reduction of corporate transparency, thus exposing registered accountants to higher audit risks and raising audit fees. The liquidity and profitability of financial products provide a convenient means for the management to implement earnings management. Listed companies can hide the deterioration of the operating conditions of their main businesses through financial 
investment returns. Financial investment becomes part of the real earnings management activities of enterprises [14]. Therefore, the hypothesis is put forward: financialization of entity enterprises will reduce the transparency of enterprises information and lead to the increase of audit fees(H2).

\section{Data and Research Design}

\subsection{Data}

The research object of this paper is China's Shenzhen ashare listed companies from 2013 to 2018, and eliminate financial insurance kind of listed companies, eliminate the real estate industry listed companies, eliminate during the period of ST and * ST listed company, relevant variables data missing, all rejected and unable to swallow the samples of listed companies, in order to reduce the influence of extreme value, the continuous variable Winsorize processing at $1 \%$ and $99 \%$ level, through the above processing, the paper finally obtained 9458 valid samples. We obtain our data from CSMAR database and Juchao information network. In this paper, data processing and analysis are completed using Stata15.

\subsection{Variable Description}

\subsubsection{Explained variable}

Cost: explained variable is measured by the natural logarithm of the audit fee.

\subsubsection{Explanatory variable}

a) Fin: (trading financial assets + dividends receivable + interest receivable + available for sale financial assets + investments held to maturity + long-term equity investments + net investment real estate)/total assets.

b) Trans: The shenzhen stock exchange shall evaluate the information disclosure of the listed company.

\subsubsection{Control variable}

a) Size: Logarithm of total assets

b) Age: Take the logarithm of the establishment year of the enterprise.

c) Lev: Total liabilities/total assets at the end of the year.

d) ROA: Year-end net profit/average total assets.

e) Loss: When the enterprise's net profit is less than 0 , the value is 1 ; otherwise, it is 0 . f) Inv: Total ending inventory/assets of the business

g) Ar: Total accounts receivable/assets at the end of the period.

h) Tq: Market value/total assets

i) Seo: Value of state-owned non-financial enterprise is 1 , otherwise is 0

j) Board: Number of directors

k) $D d b l$ : Number of independent directors/number of directors Big4: Choose the value of international big four accounting firms as 1 , or 0

l) Opi: The value of standard without reservation is 1 , otherwise is 0

m) Swi: If the accounting firm changes the value of 1 , otherwise it is 0

n) Place: It is divided into east, middle and west regions according to the registered region of the company

o) Indus: With the CSRC industry classification as the standard

p) Year: Sample year 2013-2018

\subsection{Equations}

In order to examine the impact of financialization of entity enterprises on audit fees, this paper constructs a multiple regression model (1).

$$
\operatorname{Cos} t_{i, t}=\beta_{0}+\beta_{1} \text { Fin }_{i, t}+\beta_{i} \sum \text { Controls }_{i, t}+\varepsilon_{i, t}
$$

To test the mediating effect of information transparency on financialization and audit fees, this paper constructs models (2) and (3).

$$
\begin{array}{r}
\text { Trans }_{i, t}=\beta_{0}+\beta_{1} \text { Fin }_{i, t}+\beta_{i}{\text { C } \text { Controls }_{i, t}+\varepsilon_{i, t}}_{(2)} \\
\text { Cos } t_{i, t}=\beta_{0}+\beta_{1} \text { Trans }_{i, t}+\beta_{2} \text { Fin }_{i, t}+\beta_{i} \sum \text { Controls }_{i, t}+\varepsilon_{i, t}
\end{array}
$$

\subsection{Research design}

\subsubsection{Descriptive statistics}

Table1 reports descriptive statistics for variables. Table1 shows that the mean value and median value of Fin are 0.0524 and 0.0216 respectively, which is close to the data of Gan Shengdao et al. [22]. The mean value and median value of Cost are 13.6252 and 13.5670, which are close to those of Li Xinzi [23], and the standard deviation is 0.5597 , indicating that audit fees of different listed companies are quite different. 
TABLE1 VARIABLES DESCRIPTIVE STATISTICS

\begin{tabular}{|l|l|l|l|l|l|}
\hline Variable & $\begin{array}{l}\text { Obser } \\
\text { vations }\end{array}$ & Mean & Std. & Min. & Max. \\
\hline Cost & 9458 & 13.63 & 0.56 & 12.61 & 15.37 \\
\hline Fin & 9458 & 0.053 & 0.08 & 0.00 & 0.43 \\
\hline Trans & 9458 & 0.88 & 0.33 & 0.00 & 1.00 \\
\hline Size & 9458 & 21.85 & 1.07 & 19.89 & 25.06 \\
\hline Age & 9458 & 16.72 & 5.51 & 3.00 & 39.00 \\
\hline Lev & 9458 & 0.38 & 0.19 & 0.05 & 0.84 \\
\hline ROA & 9458 & 0.05 & 0.06 & -0.22 & 0.22 \\
\hline Loss & 9458 & 0.08 & 0.28 & 0.00 & 1.00 \\
\hline Inv & 9458 & 0.12 & 0.10 & 0.00 & 0.90 \\
\hline Ar & 9458 & 0.14 & 0.11 & 0.00 & 0.81 \\
\hline Tq & 9458 & 2.30 & 1.41 & 0.92 & 9.02 \\
\hline Seo & 9458 & 0.23 & 0.42 & 0.00 & 1.00 \\
\hline Board & 9458 & 8.34 & 1.60 & 4.00 & 18.00 \\
\hline Ddbl & 9458 & 0.38 & 0.06 & 0.00 & 0.75 \\
\hline Big4 & 9458 & 0.03 & 0.16 & 0.00 & 1.00 \\
\hline Opi & 9458 & 0.97 & 0.16 & 0.00 & 1.00 \\
\hline Swi & 9458 & 0.06 & 0.23 & 0.00 & 1.00 \\
\hline & & & 0.23 & \\
\hline
\end{tabular}

\subsubsection{Correlation analysis}

preliminarily preside over hypothesis 1 . In this paper, the expansion factor test is also remembered for all variables to ensure that the variables do not have multicollinearity.

From the correlation analysis, it can be seen that audit fee (Cost) is significantly correlated with financialization of entity enterprises (Fin) at the level of $1 \%$, which

TABLE 2 CORRELATION MATRIX OF SELECTED VARIABLES

\begin{tabular}{|c|c|c|c|c|c|c|c|c|c|}
\hline & Cost & Fin & Trans & Size & Age & Lev & ROA & Loss & Inv \\
\hline Cost & 1.000 & & & & & & & & \\
\hline Fin & $0.137 *$ & 1.000 & & & & & & & \\
\hline Trans & $-0.063 *$ & $-0.045^{*}$ & 1.000 & & & & & & \\
\hline Size & $0.710^{*}$ & $0.132 *$ & $0.030 *$ & 1.000 & & & & & \\
\hline Age & $0.249 *$ & $0.138 *$ & $-0.076^{*}$ & $0.224^{*}$ & 1.000 & & & & \\
\hline Lev & $0.399 *$ & -0.011 & $-0.137 *$ & $0.510^{*}$ & $-0.353 *$ & 1.000 & & & \\
\hline ROA & $-0.081 *$ & $-0.050 *$ & $0.306^{*}$ & $-0.038 *$ & $-0.072 *$ & $-0.353 *$ & 1.000 & & \\
\hline Loss & $0.040 *$ & 0.014 & $-0.311^{*}$ & $-0.019 *$ & $0.047 *$ & $0.194^{*}$ & $-0.637^{*}$ & 1.000 & \\
\hline Inv & 0.010 & $-0.136^{*}$ & $-0.017^{*}$ & $0.023 *$ & 0.014 & $0.233^{*}$ & $-0.105^{*}$ & $0.0273^{*}$ & 1.000 \\
\hline Ar & $-0.062 *$ & $-0.201 *$ & 0.009 & $-0.129 *$ & $-0.123^{*}$ & $0.110^{*}$ & -0.013 & $-0.0292 *$ & $0.021^{*}$ \\
\hline $\mathbf{T q}$ & $-0.269^{*}$ & $0.025^{*}$ & $-0.064 *$ & $-0.412 *$ & $-0.060 *$ & $-0.266^{*}$ & $0.123^{*}$ & $0.0297 *$ & $-0.079 *$ \\
\hline Soe & $0.156^{*}$ & $0.094 *$ & $0.049 *$ & $0.321 *$ & $0.258 *$ & $0.258^{*}$ & $-0.102 *$ & $0.0458 *$ & $0.034^{*}$ \\
\hline Board & $0.157 *$ & $0.021 *$ & $0.066^{*}$ & $0.249 *$ & $0.057^{*}$ & $0.143^{*}$ & $0.013 *$ & $-0.0300 *$ & -0.001 \\
\hline Ddbl & $-0.018^{*}$ & 0.013 & $-0.044^{*}$ & $-0.045^{*}$ & $-0.011 *$ & $-0.031 *$ & $-0.033^{*}$ & $0.0400 *$ & -0.005 \\
\hline Big4 & $0.207 *$ & 0.004 & $0.021 *$ & $0.188 *$ & $0.094 *$ & $0.073 *$ & $0.025 *$ & $-0.0205^{*}$ & $-0.022 *$ \\
\hline Opi & $-0.048 *$ & -0.007 & $0.319 *$ & $0.023 *$ & $-0.046^{*}$ & $-0.125^{*}$ & $0.242 *$ & $-0.2262 *$ & 0.005 \\
\hline Swi & $0.038^{*}$ & 0.017 & $-0.036^{*}$ & $0.036^{*}$ & $0.054 *$ & 0.017 & -0.015 & 0.0106 & -0.003 \\
\hline & Ar & $\mathbf{T q}$ & Soe & Board & Ddbl & Big4 & Opi & Swi & \\
\hline Ar & 1.000 & & & & & & & & \\
\hline $\mathbf{T q}$ & 0.004 & 1.000 & & & & & & & \\
\hline Soe & $-0.168 *$ & $-0.115^{*}$ & 1.000 & & & & & & \\
\hline Board & $-0.075^{*}$ & $-0.135^{*}$ & $0.264 *$ & 1.000 & & & & & \\
\hline Ddbl & $0.020 *$ & $0.047^{*}$ & $-0.079 *$ & $-0.559 *$ & 1.000 & & & & \\
\hline Big4 & $-0.058 *$ & $-0.049 *$ & $0.103 *$ & $0.095^{*}$ & $-0.027 *$ & 1.000 & & & \\
\hline Opi & 0.008 & $-0.077^{*}$ & 0.011 & -0.001 & -0.013 & $0.019^{*}$ & 1.000 & & \\
\hline Swi & 0.007 & $0.028 *$ & 0.015 & -0.012 & -0.001 & $0.060 *$ & -0.007 & 1.000 & \\
\hline
\end{tabular}


Note: $* * *, * *$ and $*$ indicate significance at the $0.01,0.05$ and 0.10 level.

\subsubsection{Regression analysis}

In this paper, the fixed effect model is tested and selected for regression analysis. Table 3 reports the results of the hypothesis H1 test for this article. After controlling such control variables as accounting firm characteristics, the regression coefficient of Fin is significantly positive at the level of 5\%. The findings in table3 support the hypothesis $\mathrm{H} 1$.

TABle 3 FinANCIALIZATION LEVEL AND AUDiT FEES OF ENTITY ENTERPRISES

\begin{tabular}{|l|l|l|}
\hline \multirow{2}{*}{ Variable } & Cost \\
\cline { 2 - 3 } & coefficient & T-value \\
\hline Fin & $0.1457^{* * *}$ & 0.0529 \\
\hline Size & $0.3592^{* * *}$ & 0.0051 \\
\hline Age & $0.0067^{* * *}$ & 0.0008 \\
\hline Lev & $0.1520^{* * *}$ & 0.000 \\
\hline ROA & $-0.2423^{* * *}$ & 0.0869 \\
\hline Loss & $0.0367^{* *}$ & 0.0181 \\
\hline Inv & 0.024 & 0.0441 \\
\hline Ar & 0.0538 & 0.0386 \\
\hline Tq & $0.0139^{* * *}$ & 0.0034 \\
\hline Soe & $-0.1028^{* * *}$ & 0.0107 \\
\hline Board & 0.0051 & 0.0031 \\
\hline Ddbl & 0.0862 & 0.0827 \\
\hline Big4 & $0.2720^{* * *}$ & 0.0241 \\
\hline Opi & $-0.1271^{* * *}$ & 0.0255 \\
\hline Swi & -0.0102 & 0.0166 \\
\hline Place & Yes \\
\hline Indus & Yes \\
\hline Year & Yes \\
\hline N & 9458 \\
\hline R & 0.5640 & \\
\hline
\end{tabular}

Note: $* * *, * *$ and $*$ indicate significance at the 0.01 , 0.05 and 0.10 level.

Table 4 reports the test results of hypothesis $\mathrm{H} 2$ in this paper. As shown in column (1), financialization of entity enterprises significantly reduces the information transparency of entity enterprises, while it can be seen from column (2) that the reduction of information transparency increases the audit fees of entity enterprises, which verifies the hypothesis $\mathrm{H} 2$.

TABLE 4 REGRESSION RESULTS OF MECHANISM TEST

\begin{tabular}{|c|c|c|c|c|}
\hline \multirow{3}{*}{ Variable } & \multicolumn{2}{|l|}{ (1) } & \multicolumn{2}{|l|}{$(2)$} \\
\hline & \multicolumn{2}{|l|}{ Trans } & \multicolumn{2}{|l|}{ Cost } \\
\hline & coefficient & $\begin{array}{l}T- \\
\text { value }\end{array}$ & coefficient & $\begin{array}{l}T- \\
\text { value }\end{array}$ \\
\hline Fin & $\begin{array}{l}- \\
0.1433 * * *\end{array}$ & 0.0415 & $0.1653 * * *$ & 0.0526 \\
\hline Trans & & & $\begin{array}{l}- \\
0.0724 * * *\end{array}$ & 0.0130 \\
\hline Controls & \multicolumn{2}{|l|}{ Yes } & \multicolumn{2}{|l|}{ Yes } \\
\hline Place & \multicolumn{2}{|l|}{ Yes } & \multicolumn{2}{|l|}{ Yes } \\
\hline Indus & \multicolumn{2}{|l|}{ Yes } & \multicolumn{2}{|l|}{ Yes } \\
\hline
\end{tabular}

\begin{tabular}{|l|l|l|}
\hline Year & Yes & Yes \\
\hline $\mathbf{N}$ & 9458 & 9458 \\
\hline $\mathbf{R}^{\mathbf{2}}$ & 0.1938 & 0.5554 \\
\hline
\end{tabular}

Note: $* * *, * *$ and $*$ indicate significance at the 0.01 ,

0.05 and 0.10 level.

\subsubsection{Robustness test}

In order to verify the robustness of the model, this paper adopts the way of substitution variables. The calculation formula using Du Yong's financialization degree is: NFin $=$ (trading financial assets + derivative financial assets + net loans and advances + net financial assets available for sale + net investment held to maturity + net investment real estate)/total assets. As shown in table5 the coefficient of financialization is still significantly positive at the level of $1 \%$.

TABLE 5 REGRESSION RESUltS OF ROBUSTNESS TEST

\begin{tabular}{|l|l|l|}
\hline \multirow{2}{*}{ Variable } & Cost \\
\cline { 2 - 3 } & coefficient & T-value \\
\hline Nfin & $0.1399 * *$ & 0.0711 \\
\hline Controls & Yes \\
\hline Place & Yes \\
\hline Indus & Yes \\
\hline Year & Yes \\
\hline $\mathbf{N}$ & 9458 \\
\hline $\mathbf{R}^{\mathbf{2}}$ & 0.5639 \\
\hline
\end{tabular}

0.05 and 0.10 level.

\section{Conclusion and Suggestions}

Enterprise information transparency directly affects the decision-making behavior of investors and the healthy development of the capital market. By using the panel data of a-share listed companies in Shenzhen from 2013 to 2018 , this paper finds that financialization of entity enterprises has a significant positive relationship with audit fees. The internal mechanism is that the financialization of entity enterprises reduces the transparency of companies, which increases the audit risks faced by certified public accountants, thus increasing audit fees. This paper provides a new way of thinking for the capital market to focus on the financialization of entity enterprises from the perspective of enterprise information transparency. When facing the financialization of entity enterprises, certified public accountants should make accurate judgments and responses. For regulators, when formulating financial regulatory measures, they should strengthen the quality of information disclosure of listed companies, curb financial speculation by management, and reduce "adverse selection", so as to regulate the capital operation of the financial market and prevent financial risks.

At present, this paper only focuses on Shenzhen listed companies, not Shanghai listed companies. In the future, further analysis can be made and different 
methods can be used to construct information transparency indicators, so as to deepen the relationship between financialization, information transparency and audit fees of entity enterprises.

\section{References}

1. Barth, M.E., Y. Konchitchki, and W.R. Landsman. Cost of capital and earnings transparency. Journal of Accounting and Economics, 2013,55(2-3):206-224.

2. Bell T. B., W.R. Landsman, and D. A. Shackelford, Auditors' perceived business risk and audit fees: Analysis and evidence. Journal of Accounting Research, 2001(6):35-43.

3. Bell T. B., Doogar R, Solomon I. Audit Labor Usage and Fees under Business RiskAuditing. Journal ofAccounting Research, 2010,46(4):729-760.

4. Bell T. B., GriffinJB. Commentary on Auditing High-Uncertainty Fair Value Estimates.AuditingAJournalofPractice\&Theory,201 2,31(1):147 - 155 .

5. Bratten B., Gaynor L. M., McDaniel L.. The audit of fair values and other estimates:The effects of underlying environmental, task, and auditor-specific factors. Auditing:A Journal of Practice \& Theory,2013,32(sp1):7 - 44.

6. Bushman,R . M. , Piotroski, J.D. , and A.J. Smith . What Determines Corporate Transparency? Journal of Accounting Research 2004 (2): 207252 .

7. Demif F, Capital Market Imperfections and Financialization of Real Sectors in Emerging Markets: Private Investment and Cash Flow Relationship Revisited. 2009, 37(5):953-964.

8. Francis, J., et al. Costs of equity and earnings attributes[J]. The Accounting Review, 2004,79(4): 967-1010.

9. Healy, P. and K. Palepu, The effect of firms' financial disclosure strategies on stock prices. Accounting Horizons, 1993, 7(1):1-11.

10. Jin, L., Myers, SC.. R2 around the World: New Theory and New Tests. Journal of Financial Economics, 2006,79:257-292.

11. Menon K, Williams J. D. The use of audit committees for monitoring. Journal of Accounting \& Public Policy, 1994,13(2):121-139.

12. Orhangazi O.. Financialization of the U. S. economy and its effects on capital accumulation : A theoretical and empirical investigation.Boston: The Graduare School of the University of Massachusetts, 2006.
13. Roychowdhury, S. Earnings Management through real Activities Manipulation. Journal of Accounting and Economics, 2006,42:335-37.

14. Seo H. J., Kim H. S., Kim Y. C.. Financialization and the slowdown in Korean firms' R\&D investment. Asian Economic Papers, 2012,11(3):35-49.

15. Simunic, D. A., The pricing of audit services: Theory and evidence, Journal of Accounting Research (Spring), 1980:161-190.

16. Stagliano R, Rocca M, Rocca T. Agency Costs of Free Cash Flow, Internal Capital Markets and Unrelated Diversification. Review of Managerial Science,2014,8(2):145-174.

17. Theurillat T.,J. Copataux O. Crevoisier. Property sector financialization: The case of Swiss pension funds(1992-2005). European Planning Studies, 2010(2):189-212.

18. Tobin, J. Money and Economic Growth. Econometrica,1965,33(4):671-684.

19. Tori, D., Onaran, O., Evidence from Firm-level Data for the UK. Post Keynesian Economics Study Group Working Paper,2016.

20. Du Yong, Zhang Huan, Chen Jianying. The impact of financialization on future development of real enterprises' core business: promotion or inhibition. China industrial economics,2017(12): 115-133.

21. Gan Shengdao, He Yi, Xiao Liang. Is the financialization level of entity enterprises influenced by managers? - based on the perspective of managerial overconfidence. Contemporary economic management, 2008,40(02):11-16.

22. Li Xinzi, Niu Yuhao, Chen Xiao. Financial asset allocation, auditor identification and audit fees. Audit research,2019(03):93-100.

23. Lu Chuang, Niu Yuhao, Pan Liuyun, Liu Bingru. Research on the relationship between financial asset allocation and stock price crash risk. Scientific decision-making,2019(03):1-22.

24. Peng Yuchao, Ni Xiaoran, Shen Ji. The effect of transforming the economy from substantial to fictitious on financial market stability: an analysis on stock price crash risk. Economic research, 2008,53(10):50-66.

25. Sun Hongfeng, Liu Chang. Does the financialization of the enterprise affect the risk decision of the auditors? . Journal of Audit and economic,2019,34(05):54-64.

26. Wang Baiqiang, Wu Lina. Do auditors treat clients with deviated strategy differently ? Audit research,2017(5): 54-61. 